\title{
Jonlk FAKTOR - FAKTOR MOTIVASI BERNYANYI Ikonik KERONCONG PADA PENYANYI KERONCONG MUDA
}

Volume 3, Nomor 1 Januari 2021

(1-5)

\author{
Carinda Nabila Huda
}

Pengkajian Musik

Pascasarjana Institut Seni Indonesia Yogyakarta

e-mail : carindanabila21@gmail.com

\begin{abstract}
ABSTRAK
Penelitian ini bertujuan untuk mengetahui faktor - faktor yang memengaruhi motivasi seseorang yang masih berusia muda untuk belajar dan bernyanyi keroncong. Penelitian ini merupakan penelitian kualitaitif dengan wawancara semi-terstruktur sebagai teknik pengumpulan data. Wawancara dilakukan terhadap tiga narasumber, yaitu tiga penyanyi keroncong yang masih berusia muda, yakni 23, 24 dan 25 tahun. Narasumber tersebut dipilih berdasarkan tiga kriteria : berusia muda, memiliki prestasi di bidang vokal keroncong, dan sudah menjadikan bernyanyi keroncong sebagai sebuah profesi. Rekaman wawancara yang sudah terkumpul kemudian ditranskrip ke dalam bentuk tulisan, diberi kode, dan direduksi. Hasil penelitian menunjukkan bahwa faktor motivasi dalam bernyanyi keroncong dikelompokkan menjadi faktor yang berasal dari dalam individu (internal) dan faktor yang berasal dari luar individu (eksternal). Faktor internal berupa rasa penasaran, tertantang, perasaan suka, enjoy, seru, semangat, hobby dan perasaan ingin menambah pengalaman dan referensi. Sedangkan faktor yang berasal dari luar individu (eksternal) banyak datang dari saran dan dukungan dari orang - orang di sekitar individu tersebut. Seperti saran dari orangtua untuk bernyanyi keroncong, dukungan keluarga, teman, serta adanya sarana dan prasarana yang memadahi.
\end{abstract}

Kata kunci: keroncong, motivasi, penyanyi muda.

\begin{abstract}
The purpose of this research was to find out the factors that influence the motivation of someone who is young to learn and sing keroncong. The was qualitative with semi-structured interviews as a data collection technique. Interviews was conducted with three speakers. They were 23, 24, and 25 year-old-keroncong singers. The three speakers were chosen based on three criterias : young, having vocal keroncong achievments, and having a profession as keroncong singer. The interview records that have been collected are then transcribed into written form, coded, and reduced. The results showed that motivational factors in singing keroncong are grouped into factors that orginate from within the individual (internal) and factors that cone from oustide the individual (external). Internal factor such as curiosity, challenge, feeling like, enjoy, exciting, passion, hobby, and feeling want to add experience and references. While the factors that come from outside the individual (external) many come from the advice and support of the people around the individual. As suggestions from parents to sing keroncong, family support, friends, and the existence of adequate facilities and infrastructure.
\end{abstract}

Keyword: keroncong, motivation, young singer.

\section{PENDAHULUAN}

Tahun ini, keroncong Plesiran akan kembali digelar September mendatang. Acara ini digelar oleh Simphony Kerontjong Moeda, sebuah komunitas keroncong yang didominasi oleh musikus muda. Pertunjukan yang akan digelar September mendatang adalah pertunjukan Orksetra Keroncong yang akan disuguhkan oleh kalangan muda. (Razak, Abdul Hamid "Dispar DIY
Terus Promosikan Keroncong Plesiran \#3" Harian Jogja 5 Mei 2019).

Begitulah berita yang tertulis di Koran Harian Jogja. Fenomena menarik yang dapat ditemukan dari penggalan kalimat di atas adalah adanya pertunjukan keroncong yang akan diselenggarakan dan dimainkan oleh kalangan muda. Padahal biasanya, keroncong identik dimainkan dan dinikmati oleh kalangan orang yang sudah tua atau lanjut usia. Hal tersebut dibuktikan dengan siaran - 
siaran keroncong yang ada di televisi yang pemainnya didominasi oleh kalangan tua. Selain itu, pada acara pernikahan juga sering dijumpai musik keroncong yang dimainkan oleh orang yang sudah tua.

Adanya pagelaran Keroncong Plesiran, seolah memberikan fakta baru bahwa kini keroncong juga dapat menarik apresiasi dari kalangan muda. Beberapa event mengenai keroncong juga sudah digelar sebelumnya, seperti Pasar Keroncong Kotagedhe. Pada event tersebut dijumpai beberapa musisi muda yang tidak hanya membawakan repertoar keroncong, namun juga membawakan lagu pop yang aransemennya diubah menjadi keroncong.

Menurut Dinas Pariwisata DIY, pagelaran pagelaran keroncong tersebut dimaksudkan sebagai sarana melestarikan musik keroncong di era modern. Ditengah usaha Dinas Pariwisata memperbanyak serta mendukung berbagai pagelaran atau event keroncong guna sarana melestarikan keroncong, ternyata sudah ada pemuda dan pemudi yang mempelajari keroncong (berfokus pada teknik vokal keroncong) dan bahkan menjadikan bernyanyi keroncong sebagai sebuah profesi.

Penyanyi keroncong muda ini, selain memenangkan ajang bernyanyi keroncong seperti PEKSIMINAS (Pekan Seni Mahasiswa Nasional) juga berprofesi sebagai penyanyi keroncong di cafe atau pada acara - acara pernikahan. Padahal, tidak banyak orang yang masih berusia muda mau mempelajari vokal keroncong dan menjadikan bernyanyi keroncong sebagai profesi. Selain iu, vokal keroncong terbilang sullit karena ada teknik - teknik khas yang tidak semua orang bisa membawakannya.

\section{METODE PENELITIAN}

\section{Jenis Penelitian}

Penelitian ini merupakan penelitian kualitatif. Penelitian kualitatif dilakukan guna memperoleh data yang mendalam, jelas, dan rinci. Dalam hal ini, peneliti berusaha menggali infromasi mendalam, jelas dan rinci mengenai pengalaman narasumber dalam bernyanyi keroncong melalui wawancara semi terstruktur. Data tersebut kemudian dianalisa untuk mendapatkan pemahaman mengenai faktor - faktor motivasi bernyanyi keroncong pada penyayi keroncong muda.

\section{Teknik Pengumpulan Data}

Pengumpulan data dilakukan dengan menggunakan wawancara. Teknik wawancara yang digunakan adalah wawancara semi terstruktur. Alasan dipilihnya wawancara semi terstruktur dikarenakan penulis ingin tetap memiliki panduan dalam wawancara namun tidak menutup kemungkinan mengajukan pertanyaan diluar yang ada dalam pedoman wawancara.
Hal tersebut dimaksudkan untuk menggali informasi yang lebih mendalam dari narasumber. Pedoman wawancara yang dibuat berisi pertanyaan - pertanyaan wawancara yang berkaitan dengan topik penelitian. Pertanyaan - pertanyaan yang dibuat bertujuan menggali mengenai faktor - faktor yang mempengaruhi motivasi seseorang yang masih berusia muda dalam bernyanyi keroncong. Pertanyaan tersebut berusaha dibuat untuk menggali dua faktor yang mempengaruhi motivasi bernyanyi keroncong, yaitu faktor internal (yang berasal dari dalam individu) dan faktor eksternal (yang berasal dari luar individu).

Wawancara dilakukan secara langsung, yaitu bertatap muka langsung dengan narasumber. Hal tersebut dilakukan dengan tujuan mendapat data yang mendalam, dan mengurangi adanya kesalahan informasi atau data yang simpang siur. Untuk dapat melakukan wawancara secara langsung, terlebih dahulu dilakukan beberapa tahap, yaitu menghubungi narasumber, mengatur pertemuan (menentukan tempat dan waktu).

\section{Penentuan Narasumber}

Penelitian ini dilakukan dengan wawancara terhadap tiga narasumber, yaitu tiga penyanyi keroncong yang masih berusia muda. Usia mereka adalah 23, 24, dan 25 tahun. Alasan dipilihnya tiga narasumber tersebut dikarenakan mereka sudah profesional dalam bernyanyi keroncong Profesional yang dimaksudkan disini adalah mereka memang sudah menjadikan bernyanyi keroncong sebagai profesi. Ada yang bernyanyi keroncong di cafe, adapula yang bernyanyi keroncong di acara pernikahan. Selain itu, ketiga narasumber juga pernah mengikuti perlombaan vokal keroncong tingkat nasional (Pekan Seni Mahasiswa Nasional) dan berhasil masuk kedalam 3 besar, bahkan ada yang juara 1 nasional. Untuk itu, peneliti memilih ketiga narasumber ini untuk diwawancara karena dianggap sesuai dengan kriteria yang dibutuhkan dalam penelitian, yaitu berusia muda, mampu bernyanyi keroncong, dan sudah menjadikan bernyanyi keroncong sebagai profesi

Narasumber pertama berusia 23 tahun yang merupakan alumni Seni Musik Institut Seni Indonesia yang bernyanyi keroncong di cafe dan acara pernikahan. Selain itu, narasumber juga merupakan juara 1 Bintang Radio vokal keroncong tingkat Nasional tahun 2012, dan juara 3 vokal keroncong putri Pekan Seni Mahasiswa Nasional tahun 2019. Narasumber kedua berusia 24 tahun, merupakan alumni Seni Musik Universitas Negeri Yogyakarta yang bernyanyi keroncong di acara acara pernikahan dan menjadi juara 2 vokal keroncong putri Pekan Seni Mahasiswa Nasional tahun 2016. Narasumber ketiga berusia 25 tahun yang merupakan alumni Seni Musik Universitas Negeri Yogyakarta, bernyanyi keroncong di acara 
pernikahan dan merupakan juara 2 vokal keroncong putra Pekan Seni Mahasiswa Nasional tahun 2014 dan 2016.

\section{Teknik Analisis Data}

Teknik analisis data dilakukan dengan cara transkripsi data wawancara ke dalam bentuk tulisan. Tahap analisis data yang akan dilakukan adalah sebagai berikut :

a. Rekaman suara (audio) selama wawancara berlangsung ditranskripsi secara verbatim ke dalam bentuk tulisan.

b. Data rekaman yang sudah selesai ditranskrip kemudian diberi kode dengan menggunakan kata yang mewakili setiap keterangan dari narasumber tersebut. Penulis melakukan pengodean sebanyak dua kali. Kode tahap pertama terdapat 30 kode. Selanjutnya kode tersebut direduksi lagi dan dikelompokkan lagi menjadi dua kode, yaitu "Faktor Internal" dan "Faktor eksternal". Faktor Internal berisi kode - kode yang berkaitan dengan faktor motivasi yang berasal dari dalam diri individu Faktor eksternal berisi kode - kode yang berkaitan dengan faktor - faktor motivasi yang berasal dari luar individu.

\section{HASIL DAN PEMBAHASAN}

Berdasarkan wawancara yang sudah dilakukan, didapatkan penemuan berupa faktor faktor motivasi bernyanyi keroncong pada penyanyi keroncong muda. Macam - macam faktor motivasi tersebut dapat dilihat pada matriks berikut :

\begin{tabular}{|c|l|l|}
\hline \multirow{2}{*}{ Wawa } & \multicolumn{2}{|c|}{ Faktor - Faktor Motivasi Bernyanyi } \\
\cline { 2 - 3 } ncara & Faktor Internal & Faktor Eksternal \\
\hline 1. & $\begin{array}{l}\text { Modal, cari } \\
\text { pengalaman, } \\
\text { merasa tertantang, } \\
\text { seru, senang, } \\
\text { hobby, rasa } \\
\text { penasaran, } \\
\text { antusias, }\end{array}$ & $\begin{array}{l}\text { Permintaan ibu, } \\
\text { lingkungan } \\
\text { keluarga, } \\
\text { dukungan } \\
\text { keluarga, } \\
\text { membawa nama } \\
\text { kampus, } \\
\text { dukungan teman, } \\
\text { dukungan guru, } \\
\text { matakuliah } \\
\text { keroncong, } \\
\text { dukungan grup, } \\
\text { alat tersedia }\end{array}$ \\
\hline 2. & $\begin{array}{l}\text { Rasa penasaran, } \\
\text { senang, mencari } \\
\text { pengalaman, }\end{array}$ & $\begin{array}{l}\text { Permintaan } \\
\text { guru, dukungan } \\
\text { guru, dukungan }\end{array}$ \\
\hline
\end{tabular}

\begin{tabular}{|c|l|l|}
\hline & $\begin{array}{l}\text { mengasah } \\
\text { kemampuan, } \\
\text { menambah teman, } \\
\text { menambah } \\
\text { referensi, } \\
\text { menambah } \\
\text { pengetahuan }\end{array}$ & $\begin{array}{l}\text { grup, latihan } \\
\text { rutin, tempat } \\
\text { tersedia, lebih } \\
\text { dihargai, } \\
\text { dukungan } \\
\text { keluarga, } \\
\text { lingkungan } \\
\text { keluarga, alat } \\
\text { tersedia, }\end{array}$ \\
\hline 3. & $\begin{array}{l}\text { Ingin tampil, } \\
\text { senang, rasa } \\
\text { penasaran, enjoy, } \\
\text { merasa tertantang, } \\
\text { tertarik, berminat, } \\
\text { menambah } \\
\text { semangat, hobby, } \\
\text { suka. }\end{array}$ & $\begin{array}{l}\text { Permintaan } \\
\text { Bapak, dukungan } \\
\text { teman, dukungan } \\
\text { keluarga, } \\
\text { dukungan guru, } \\
\text { dukungan grup, } \\
\text { latihan rutin, alat } \\
\text { tersedia, tempat } \\
\text { tersedia. }\end{array}$ \\
\hline
\end{tabular}

Tabel 1. Faktor - Faktro Motivasi Bernyanyi Keroncong

Matriks tersebut berisi kode dari faktor faktor motivasi dalam bernyanyi keroncong dan dibagi kedalam dua kelompok, yaitu faktor internal dan faktor eksternal. Faktor yang berasal dari dalam diri individu (internal) meliputi rasa penasaran, tertantang, perasaan suka, enjoy, merasa seru, semangat, hobby dan perasaan ingin menambah teman, pengalaman dan referensi. Sedangkan faktor yang berasal dari luar individu (eksternal) banyak datang dari orang - orang di sekitar individu tersebut. Seperti dukungan orangtua, teman, keluarga, dan adanya sarana dan prasarana yang memadahi.

\section{Pembahasan \\ Faktor Internal}

Berdasarkan hasil wawancara, faktor internal yang paling menonjol adalah rasa penasaran dan tertantang. Ketiga narasumber mengatakan bahwa mereka merasa penasaran dan merasa tertantang untuk bernyanyi keroncong. Hal tersebut membuat mereka mempelajari vokal keroncong dan akhirnya mampu bernyanyi keroncong. Ketiga narasumber mengatakan bahwa vokal keroncong sangat susah, sehingga mereka merasa penasaran dan tertantang untuk bernyanyi keroncong. Hal tersebut juga dikuatkan dengan pernyataan narasumber ketika ditanya mengenai alasan tertarik dengan vokal keroncong. Narasumber tersebut mengutarakan jawabannya sebagai berikut,

Ya karena susahnya itu. Itu menjadi tantangan buat saya mulai dari SMA itu benar - benar mulai sangat sangat serius.

Selain itu, jurnal berjudul Analisis Pembawaan Vokal Sri Hartati pada Lagu Keroncong Tanah Airku 
Karya Kelly Puspito yang ditulis oleh Dhara Lastarya Jan menyebutkan bahwa masih ditemui banyak penyanyi yang memiliki kendala dalam bernyanyi keroncong. Hal ini dikarenakan vokal keroncong memiliki teknik - teknik dan ciri khas tersendiri yang sulit dibawakan. Kendala - kendala yang sering ditemui antara lain kurang menguasai teknik pernafasan, sehingga kurang bisa mencapai nadanada panjang, kurang menguasai teknik - teknik khusus dalam bernyanyi keroncong seperti cengkok, nggandul, luk dan embat. Selain itu, kendala bernyanyi keroncong adalah kurang tepat dalam menempatkan teknik cengkok, nggandul, luk dan embat ketika bernyanyi. Kendala dan kesulitan tersebut yang dirasakan oleh narasumber mampu membuat penasaran, antusias dan tertantang, sehingga mereka termotivasi untuk dapat bernyanyi keroncong.

Faktor internal lain yang banyak disebut oleh ketiga narasumber adalah perasaan menikmati dalam proses belajar keroncong hingga bernyanyi keroncong yang digambarkan dengan perasaan suka, seru, dan enjoy. Hal tersebut sejalan dengan jurnal The Sankofa Drum and Dance Ensemble : Motivations for student participation in a school world music ensemble yang membahas mengenai alasan siswa bergabung di Sangkofa Drum and Dance Ansamble. Hasilnya menyebutkan bahwa alasan siswa mengikuti ansambel tersebut karena adanya motivasi musikal, psikologis dan sosial. Motivasi musikal diantaranya adalah ada rasa ketertarikan terhadap musik, perasaan menyukai musik, dan perasaan menikmati musik yang mereka mainkan.

\section{Faktor Eksternal}

Faktor eksternal merupakan faktor - faktor yang berasal dari luar individu dan mempengaruhi motivasi dalam bernyanyi keroncong. Berdasarkan wawancara yang sudah dilakukan. Ketiga narasumber mengatakan bahwa awal mula mereka terjun di dunia keroncong dikarenakan ajakan atau permintaan dari orang lain (orang tua atau guru). Permintaan dan dukungan orang - orang terdekat, seperti keluarga memang mampu meningkatkan motivasi dalam bernyanyi keroncong. Hal tersebut juga dipaparkan oleh salah satu narasumber ketika ditanya mengenai alasan mempelajari vokal keroncong. Narasumber tersebut mengatakan bahwa,

Itu Bapak saya yang ngajarin. Kebetulan kan Bapak, aaa guru seni musik ya, sering main - main lagu, ya banyak lagu. Terus, ada lagu yang katanya paling sulit untuk dipelajari adalah keroncong. Terus mulai dari itu, belajar lagu keroncong.
Selain itu, jurnal berjudul Self-determination theory : An approach to motivation in music education yang ditulis oleh Paul Evans menyebutkan bahwa motivasi belajar musik diyakini akan berlangsung hingga kebutuhan psikologis terpenuhi. Motivasi tersebut ada yang internal dan eksternal. Salah satu motivasi eksternal adalah saran dari orangtua. Banyak siswa yang mulai belajar karena saran dari orangtua yang meminta anak untuk tergabung dalam ekstrakulikuler musik..

Selain adanya dukungan dari orangtua, ketiga narasumber mengatakan adanya dukungan dari orang - orang terdekat, seperti teman, baik teman dalam grup keroncong maupun teman diluar grup keroncong. Salah satu narasumber mengatakan, jika tidak ada dukungan dari teman (terutama teman yang berasal dari dalam grup keroncong) tidak mungkin narasumber tersebut bisa bernyanyi keroncong. Dalam jurnal Peers, parents and teachers : A case study on how popular music guitarist perceive support for expertise development from "persons in the shadows" dijelaskan pentingnya dukungan dari teman. Jurnal tersebut menyebutkan bahwa dukungan dalam keahlian bermusik datang dari tiga golongan : teman, orangtua, dan guru. Hasilnya menyebutkan bahwa dukungan teman memiliki pengaruh yang paling besar dibandingkan dukungan orangtua dan guru. Teman sebaya dan band yang terbentuk dapat berpengaruh besar dalam membantu proses latihan. Hal itu yang menyebabkan dukungan teman paling berpengaruh dibandingkan orangtua dan guru.

\section{Keterkaitan antara Faktor Internal dan Eksternal.}

Berdasarkan hasil wawancara yang dilakukan terhadap ketiga narasumber, ditemui keterkaitan antara faktor eksternal dan internal. Faktor eksternal pendukung motivasi bernyanyi keroncong dapat menumbuhkan faktor internal yang juga mendukung dalam bernyanyi keroncong. Sebagai contoh, awal mula ketiga narasumber bernyanyi keroncong karena adanya permintaan dari orangtua (faktor eksternal). Setelah mencoba bernyanyi keroncong, lama kelamaan mereka menikmatinya, dan tumbuh rasa penasaran, tertantang, seru, dan enjoy dalam bernyanyi keroncong (faktor internal).

Hal tersebut juga diperkuat dengan juranl yang berjudul Intrinsic-Extrinsic in Sport Motivation yang mengatakan bahwa faktor intrinsik tidak lepas dari faktor ekstrinsik. Faktor ekstrinsik, seperti dukungan dari pihak lain dapat meningkatkan harga diri dan motivasi intrinsik. 


\section{PENUTUP}

Penelitian ini bertujuan untuk mengetahui apa saja faktor yang mempengaruhi motivasi bernyanyi keroncong pada penyanyi keroncong muda. Berdasarkan hasil penelitian, faktor motivasi dikelompokkan menjadi faktor yang berasal dari dalam individu (internal) dan faktor yang berasal dari luar individu (eksternal). Faktor internal berupa rasa penasaran, tertantang, perasaan suka, enjoy, seru, semangat, hobby dan perasaan ingin menambah pengalaman dan referensi. Sedangkan faktor yang berasal dari luar individu (eksternal) banyak datang dari saran dan dukungan dari orang - orang di sekitar individu tersebut. Seperti saran dari orangtua untuk bernyanyi keroncong, dukungan keluarga, teman, keluarga, dan adanya sarana dan prasarana yang memadahi.

\section{DAFTAR PUSTAKA}

Evans, Paul. (2015). "Self-determination theory : Anapproach to motivation in music education", Musicae Scientiae 19(1): 65-83.

Hess, Juliet. (2010). "The Sankofa Drum and Dance Ensemble : Motivations for student participation in a school world music ensemble", Research Studies in Music Education 32(1): 23-42.

Jan, Dhara Lastarya. (2017). "Analisis Pembawaan Vokal Sri Hartati pada Lagu Keroncong Tanah Airku Karya Kelly Puspito”, Jurnal Tugas Akhir 113.

Langler, Manuel, Markus Nivala, Hans Gruber. (2017)."Peers, parents and teachers : A case study on how popular music guitarist perceive support for expertise development from "persons in the shadows", Musicae Scientieae 120.

Pedersen, Darhl M. (2002). "Intrinsic-Extrinsic in Sport Motivation", Perceptual and Motor Skills 95(2): 459-476. 